are seen at a distance or in a large group. For example, although males are usually larger than females, mals. Olson distinguishes seven life-stages for bison: calves, yearlings, two-year-olds, young adults, mature adults, dominant males, and aged bison. He points out that for wildlife biologists, knowing the age structure and composition of a bison herd is important for making management decisions. However, recognizing different generations of bison can also add interest to a hike or nature ramble. Just as birders recognize birds by plumage and songs, bison watchers must learn to distinguish different pelage stages, body structure, and horn shapes.

The book continues with four appendices, focusing on age and sex determination from the skull, a list of public bison herds in North America, a summary reiterating the main features of male and female life stages, and a blank data sheet for recording observations on bison herd structure. The age and sex determination focuses on a few critical plains bison skull measurements and tooth eruption and wear patterns in the lower jaw or mandible. Olson mentions one criterion for distinguishing bison from cattle skulls. I found this section a bit brief. Within a national park or a wildlife refuge with a bison herd one can assume that skulls are mostly going to be from bison. However, this is not the case across the prairies at large, where people often find skulls, or more usually parts of skulls, that they think may be bison. I felt that more information on distinguishing bison from other faunal remains would have made this section more generally this size difference is not as marked in younger ani-

useful. The volume concludes with a helpful reference list, comprising many general and scholarly works on bison behaviour and biology. The book is large-format ( $27.5 \mathrm{~cm}$ wide by $25.5 \mathrm{~cm}$ high), giving plenty of space for the photographs and drawings, and is printed on high-quality glossy paper. The images are well laid-out and, for the most part, crisply rendered.

This is an unusual book. I certainly have not come across anything quite like it before. It is not really a field guide, since the format does not lend itself well to being stuffed in a pocket. It is not really a text book, because the emphasis is on identification, observation, and field work. This book will certainly be relevant to anyone who works with bison in the field or has an interest in bison population studies, wildlife biology, or ecology. However, I think it has much broader appeal and will also intrigue anyone who simply likes watching bison and wants to learn more about them. The book can also be enjoyed on a purely aesthetic level, because the photographs and drawings are in themselves so attractive and fascinating. Those of us fortunate enough to live near Elk Island National Park can see bison in the flesh, large lumbering presences moving through aspen groves, or dozing in summer sunlight. Armed with information from this book, bison spotting can have another dimension, as you try to work out who's who in the herd.

Alwynne B. BeAudoIn

Royal Alberta Museum, 12845-102 ${ }^{\text {nd }}$ Avenue, Edmonton, Alberta T5N 0M6 Canada

\section{The Buffalo Wolf, Predators, Prey and the Politics of Nature}

By Lu Carbyn. 2003. Smithsonian Books, Washington, D.C. USA. 248 pages. U.S.\$24.95. Cloth.

"It might be said that the wolf was one of the last natural resources to be included in the great modern movement toward conservation." This statement appeared in the late 1960s in one of the most impressive and enjoyable books about wolves that has ever been written (Rutter and Pimlott 1968). Conservation has come a long way, both generally and specifically with regard to the wolf. People who have led the way are few in number. Lu Carbyn is one of them. His devotion to conservation and wilderness is evident in this book which centres on wolves and bison in the PeaceAthabasca delta region of Wood Buffalo National Park.

The first chapter contains some very graphic descriptions of wolves attacking and killing bison. This is disturbing, but the reader is challenged to accept that the health of the ecosystem lies in the survival of the predators. In contrast, the second chapter sets the stage, describing Wood Buffalo Park and providing some biological background. The real story begins with the third chapter. It presents observations made during the early days of the research in Wood Buffalo
Park. The social structure of the pack as it relates to the interactions with bison is described in some depth. The fourth chapter outlines some of the fascinating results of aerial surveys. Chapters 5, 6, 7 and 8 mostly have to do with field studies that followed the termination of the Canadian Wildlife Service program in 1984. Adventures with film crews are a major feature.

Chapter 9 includes some experiences during later solo visits to the delta. The debate over whether or not to eradicate the Wood Buffalo bison herd is the main focus of the last three chapters. This debate had its origin in the introduction and "contamination" of the park's wood bison with plains bison stock from Wainright. Not only were the park bison impure, they carried diseases that also infect cattle. On the other hand there may always have been hybrids and maybe it is unlikely that herds can be protected indefinitely from some or all diseases so better to let nature take its course. Alleged declining numbers of bison in the park fanned the fire of eradication, but "how much management is too much?" After years of first hand study Carbyn believed that the wolves were the main factor in the fluctuating numbers of bison but he pointed out that parts of the big picture are still not avail- 
able and more information is needed to predict the future of the park bison. The author cleverly leads us through this debate showing how views changed and how personal agendas and politics have played a role at the expense of science. He concludes that "if other human priorities are set in place, then enlightenment, not agendas, should rule the day." Selected references and an index help to make this book a source of enlightenment for the management of the buffalo wolf ecosystem.

The book will appeal to a wide audience and is perhaps structured to do that. As a biologist I would have appreciated a little more development in some areas, perhaps at the expense of information about people. The differentiation of Plains and Wood bison was not sufficiently explained. There are some interesting aspects to discuss here (for more information on separating the two kinds of bison and other information, see Mitchell and Gates 2002). As another example, much more could have been said about the starlings observed perching on the bison in chapter 3 . They are a reminder of the impact of humans, even in this remote wilderness. They spread from a flock introduced to New York City in 1890. At the time this may have been the furthest north that they had spread in Canada and clearly they were not confined to human habitations such as Fort Smith. This is additionally interesting because it is a reminder of another careless introduction which contributed later to the major bison controversy in Wood Buffalo Park. Although I would like to have seen more in some areas, the book is not without anecdotes including subjects such as pollination of waterlilies, history of bush pilots, change in traditional experience of nature by native people and movement distances of lynx. etc. It is probably a good thing that Carbyn is able to focus to the extent that he does because there is so much to say in the experience of nature in the Canadian north.

Like most dedicated biologists and teachers, Carbyn has taken a number of hard hits. One of these was when the CWS wolf study program was terminated.

\section{Grassland Grouse and their Conservation}

By Paul A. Johnsgard. 2002. Smithsonian Institution Press, Washington, D.C. Hardcover. 157 pages. \$34.95 U.S.

When Paul Johnsgard perceived that most grassland races of grouse had decreased in numbers since he wrote The Grouse of the World in 1983, and that some were apparently doomed to follow the "Heath Hen" into extinction, he responded by writing yet another book. Johnsgard is well qualified for the task. He writes lyrically, draws exquisite sketches, and is cited in the Seventh American Ornithologists' Union CheckList as an authority on the taxonomy of the Greater and Lesser prairie-chicken.

The first chapter deals with the decline of the Heath Hen and its final extirpation on Martha's Vine-
Of course many government programs are not based on long term visionary thinking, but I am not sure that I can accept Carbyn's view that this is usually a consequence of leaders lacking vision. Leaders are often just not strong enough to break away from the constraints of ignorance surrounding them. Without actually saying so, Lu Carbyn reminds us that independent and visionary thought as well as implementation of personal goals are characteristic of some people. Fortunately, these people help to compensate for the lack of long term visionary thinking elsewhere. Carbyn has a message for biologists. He describes how in field study, intuition and imagination play an important role. We are reminded to think like a scientist but not to the exclusion of being a naturalist. He notes that "we should be taking from nature... a sense of what it is rather than its soul." The style of writing is personal and conversational with digressions and flashbacks. It is a very pleasant read.

This book promotes wilderness which is a part of Canadian heritage and identity and this alone makes it a valuable contribution. It also presents a fascinating biological and historical perspective on wolves and bison in Wood Buffalo Park. It introduces the world of a biologist. It will bring to many readers an understanding of the science, issues and politics of biology. Anyone can learn from it and enjoy it. By educating in numerous ways it will contribute to the protection of nature. It should be a source of pride for Canadian field biologists.

PAul M. CATLING

170 Sanford Avenue, Ottawa, Ontario K2C 0E9 Canada

\section{Literature Cited}

Mitchell, J. A., and C. C. Gates. 2002. Status of the Wood Bison (Bison bison athabascae) in Alberta. Alberta Sustainable Resource Development, Fish and Wildlife Division, and Alberta Conservation Association, Wildlife Status Report Number 39, Edmonton, Alberta. 32 pages. http://www3.gov.ab.ca/srd/fw/status/reports/bison/ body.html

Rutter, R. J., and D. H. Pimlott. 1968. The world of the wolf. J. B. Lippincott Company. New York. 202 pages.

yard, off the coast of Massachusetts. The remainder of the book provides us with a detailed account of recent population trends among the various races of grassland grouse, and provides current rough population estimates for each. Such detailed state-by-state accounts of declining ranges and populations for almost all races makes for depressing reading.

The Lesser Prairie-Chicken, whose closest ecological partners are Shinnery Oak and Sand Sage, is holding its own in one part of Kansas, but its range has decreased greatly in each of its five states. In New Mexico, the population has dropped from 40000 to 1000; in Oklahoma, from 15000 to less than 3000; in Colorado, numbers have dropped by about 97 per cent; in Texas it has dropped to about one-third of one per 